\title{
Transport of feed selenium to different tissues of bulls
}

\author{
BY PÄIVI EKHOLM ${ }^{1}$, PERTTI VARO ${ }^{1 *}$, PENTTI ASPILA ${ }^{2}$, \\ PEKKA KOIVISTOINEN ${ }^{3}$ AND LIISA SYRJ ÄLÄ-QVIST ${ }^{2}$ \\ Departments of ${ }^{1}$ General Chemistry, ${ }^{2}$ Animal Husbandry and ${ }^{3}$ Food Chemistry and Technology, \\ University of Helsinki, Viikki, SF-00710 Helsinki, Finland
}

(Received 2 April 1990 - Accepted 12 October 1990)

\begin{abstract}
The effects of different types of Se supplementation on the selenium concentration of beef, bovine internal organs and some other tissues were studied. The animals (thirty-two bulls) were kept in four dietary groups from birth until to the age of 13-14 months, and fed on rations containing either $0.03 \mathrm{mg} \mathrm{Se} / \mathrm{kg}$ (basic level in local feeds), $0.25 \mathrm{mg}$ inorganic Se supplemented as sodium selenite, or 0.25 or $0.4 \mathrm{mg} / \mathrm{kg}$ plant Se in dry matter from feed produced by spraying with sodium selenite. Samples of four muscles and ten other tissues and organs were taken at slaughter. Se was determined by an electrothermal atomic absorption method. Se supplementation significantly increased the Se concentration of all tissue samples. The maximum response was caused by the diet containing $0.40 \mathrm{mg} / \mathrm{kg}$ plant Se. In muscles, this diet raised the Se concentration by a factor of 10-12. In other samples, the increment was 1.5-7.5 fold, depending on the type of tissue. In general, plant Se raised the Se level more effectively than inorganic Se. Se supplementation did not affect the vitamin $E$ status of muscle tissue.
\end{abstract}

Se supplementation: Se content in tissues: Beef: Bovine liver: Edible offal

In the early 1970s, selenium and vitamin E deficiencies were still important causes of a number of diseases in Finnish livestock (Oksanen, 1965; Oksanen \& Sandholm, 1970; Sankari, 1985). The Se content of locally-produced feeds was low because the natural concentration of available Se in Finnish soils is exceptionally low (Sippola, 1979). All commercial feeds have been supplemented with sodium selenite $(0 \cdot 1 \mathrm{mg} \mathrm{Se} / \mathrm{kg})$ since 1969 . This, together with the use of Se treatments in veterinary medicine, has effectively reduced the incidence of Se deficiency diseases.

For reasons related to human nutrition and public heaith, Finnish authorities required that the Se content of domestic agricultural products should be increased by the addition of sodium selenate to all multinutrient fertilizers from autumn 1984 (Ministry of Agriculture and Forestry, 1984; Huttunen \& Koivistoinen, 1985). This procedure effectively increased the Se concentration of feeds. For example, in the mid 1970s and in 1987 the Se level of oats was $<0.01$ and $0.13 \mathrm{mg} / \mathrm{kg}$ respectively, and that of dry hay 0.01 and $0.15 \mathrm{mg} /$ kg respectively (Sippola, 1979; Varo et al. 1980; Ministry of Agriculture and Forestry, 1989). The selenate in fertilizer is presumably mainly transformed to organic compounds in plants (Gissel-Nielsen \& Bisbjerg, 1970).

The present study, which is part of a larger project concerned with the role of Se in milk and beef production (Finnish Association of Academic Agronomists, 1987), investigated the Se status of meat, internal organs and some other tissues when feeds had been supplemented with different types and levels of Se. The experimental results were also compared with the actual Se levels in bovine organs and tissues prevailing in 1988, 3 years

\footnotetext{
* For reprints.
} 
Table 1. Description of samples

\begin{tabular}{ll}
\hline Sample & Anatomical location \\
\hline $\begin{array}{l}\text { Muscle tissues of Ox beef }(1 \mathrm{~kg} \text { each }) \\
\text { Brisket boneless }\end{array}$ & Cranial from the 7 th rib \\
Chuck boneless & Cranial from the 7 th rib \\
Rib eye muscle & Caudal from the 7th rib \\
Top round & Cranial \\
Other tissues & \\
Liver & Lobus caudatus \\
Kidneys & One whole \\
Heart muscle & Right side, lower part \\
Brains & Whole \\
Spleen & Middle strip, 100-120 mm \\
Pancreas & Whole \\
Testicle & One whole \\
Bone marrow & Yellow clean tissue, front leg \\
Tendon & Front leg \\
Hair & Forehead, cut off along the skin \\
\hline
\end{tabular}

after the initiation of the general Se supplementation of fertilizers in Finland. The effect of different levels of Se supplementation on the vitamin $E$ status of beef is reported.

\section{MATERIALS AND METHODS}

Animals and sampling

The feeding study was carried out in $1984-5$ (diet groups 1-4). The random samples from the general beef production were collected in 1988 (group 5). The feeding study material consisted of thirty-two bulls, eight animals in each diet group (nineteen Friesian, eleven Friesian-Limousin crossbreds and two Friesian-Hereford crossbreds).

In group 1 , the feed contained $0.03 \mathrm{mg} \mathrm{Se} / \mathrm{kg}$ dry matter which was the basic level in local feeds before 1985. In group 2, feed was supplemented with inorganic Se to $0.25 \mathrm{mg} / \mathrm{kg}$ dry matter. The bulls of groups 3 and 4 were fed diets containing 0.25 and $0.40 \mathrm{mg}$ plant Se $/ \mathrm{kg}$ dry matter respectively. The inorganic Se (group 2) was given as sodium selenite; plant Se (groups 3 and 4) was given in feed (silage and barley) and, during the first 2 months, as sodium selenate and high Se yeast mixed into liquid milk formula. Selenite-treated silage was produced by spraying sodium selenite on growing grass 1 week before cutting, and selenite-treated barley by spraying sodium selenite on growing barley coming into awn.

The animals were fed on the experimental diets from birth to slaughter at the age of 13-14 months. Four muscle and ten other samples were taken from each animal (Table 1).

In spring 1988, 3 years after general Se fertilization had started in Finland, some of the same items were collected from a large slaughter house in the south of the country. This time four samples of each item were taken. Sampling details are given in Table 1.

The samples were homogenized (exception: bone marrow, tendon and hair), freeze dried and stored at $-20^{\circ}$ until analysed. The samples for tocopherol analyses were packed in ice in the dark for transportation to the laboratory, homogenized under reduced light, vacuum packed and stored frozen at $-20^{\circ}$ until analysed.

\section{Chemical analysis}

Se. Se was analysed by the electrothermal atomic absorption spectrometric method previously described for food samples (Kumpulainen et al. 1983). The dried samples were digested in a mixture of concentrated nitric acid, perchloric acid and sulphuric acid. Se was 
Table 2. Accuracy and precision of selenium analyses

(Mean values and standard deviations)

\begin{tabular}{|c|c|c|c|c|c|}
\hline \multirow[b]{2}{*}{ Reference } & \multirow{2}{*}{$\begin{array}{l}\text { No. of } \\
\text { determin- } \\
\text { ations }\end{array}$} & \multicolumn{2}{|c|}{ Se $(\mu \mathrm{g} / \mathrm{kg} \mathrm{DM})$} & \multicolumn{2}{|c|}{ Reference value } \\
\hline & & Mean & SD & Mean & SD \\
\hline NBS* 1577 a bovine liver & 2 & 660 & $\dagger$ & 710 & 70 \\
\hline Unofficial liver standard & 39 & 570 & 30 & & \\
\hline Unofficial meat standard & 9 & 110 & 10 & & \\
\hline
\end{tabular}

DM, dry matter.

* National Bureau of Standards.

$\dagger$ Range $660-670 \mu \mathrm{g} / \mathrm{kg} \mathrm{DM}$.

reduced to Se IV, chelated with ammonium pyrrolidine dithiocarbamate and extracted into methyl isobutyl ketone for atomic absorption spectrophotometric determination (Perkin Elmer 5000, HGA 500). The accuracy and the precision of the method were tested by determining NBS 1577a bovine liver twice, an unofficial meat standard nine times and an unofficial liver standard sample every day during the analytical period. The results of these determinations are shown in Table 2 . They suggest that the values should be rounded off to the nearest $10 \mu \mathrm{g} / \mathrm{kg}$ in values $<1000 \mu \mathrm{g} / \mathrm{kg}$ and to the nearest 100 in values $>1000 \mu \mathrm{g} / \mathrm{kg}$.

Tocopherols. Tocopherols were analysed by the high-performance liquid chromatographic method previously described for meat samples by Piironen et al. (1985). Saponification at room temperature was used. Tocopherols were extracted with $n$-hexane, separated in LiChrosorb Si 60 column at $37^{\circ}$ and eluted with $n$-hexane-diisopropyl ether. Recovery was determined by adding known amounts of $\alpha$-tocopherol to the beef samples and carrying out the analytical procedure as in other samples. The recovery of $\alpha$-tocopherol was $98.1 \%$.

Fat. The fat content of the samples was determined at the Research Institute of Meat Industry, Hämeenlinna, by a nuclear magnetic resonance method.

\section{Statistical analysis}

The statistical analysis of the results was carried out with a microcomputer using Survo 84C statistical software (Mustonen 1987). The data were tested by analysis of variance using the Brown and Forsythe F-test and the T3 test. These tests were chosen because they do not require equal group variances (Brown \& Forsythe, 1974). In the present study the group variances grew with increasing feed Se. This was tested by the Levene test (Levene, 1960). The differences between the variances were significant $(P<0.01)$.

\section{RESULTS}

The Se contents of meat and other tissues from the animals of the four dietary groups are shown in Table 3. Samples from the general beef production were collected in spring 1988. Different cuts of meat, with all the visible fat trimmed off, were nearly equal in Se content.

As expected, kidneys and testicles contained the highest amounts of Se; the Se content of bone marrow remained very low in all groups.

It is seen that the Se content of muscle tissue responded most effectively to plant Se. In group 4, the Se content of different cuts of meat was increased 10-12 fold compared with the basal level. However, inorganic Se (group 2) raised the Se content of liver and heart 
P. EKHOLM AND OTHERS

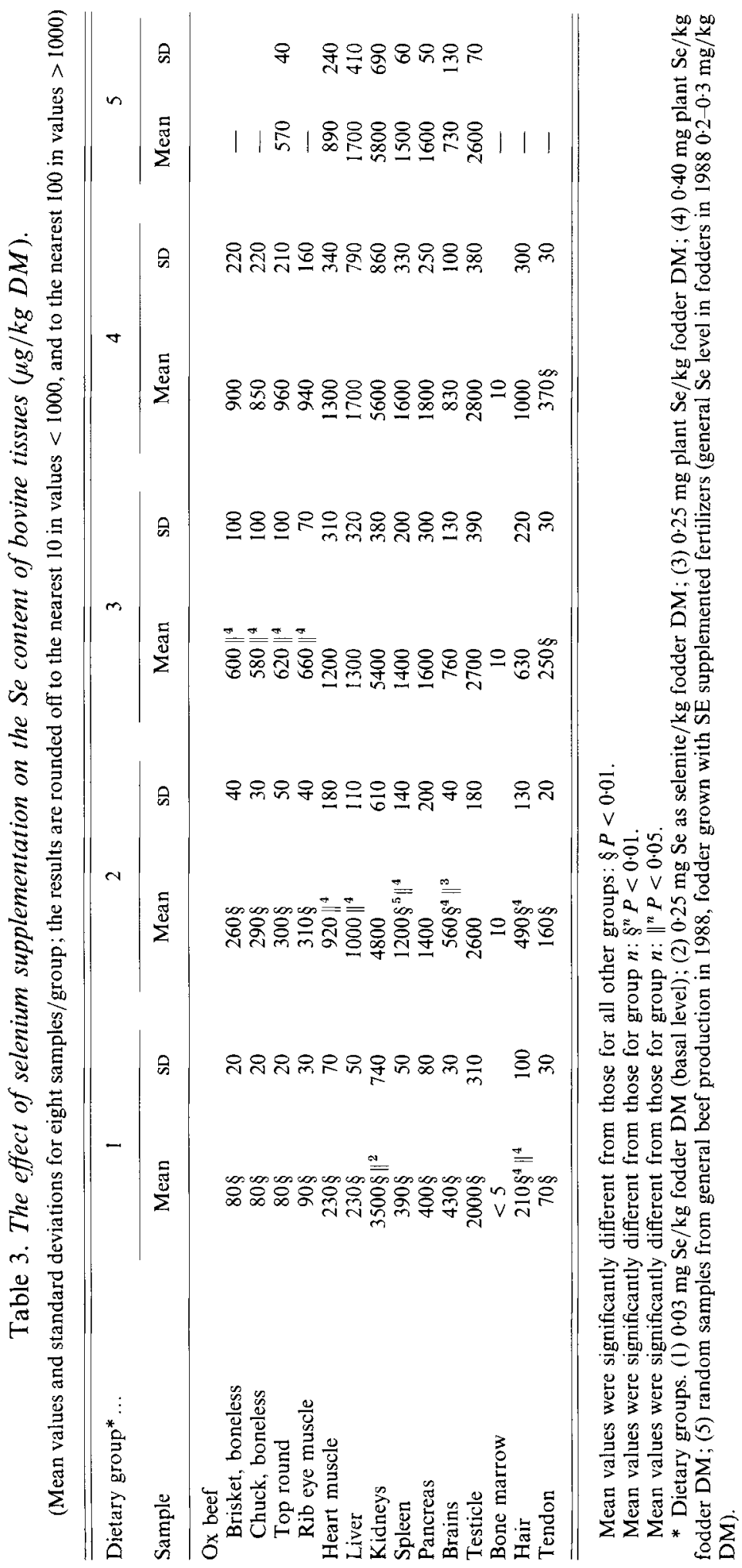


Table 4. Effect of Se supplementation on $\alpha$-tocopherol concentration of ox beef top round (moisture $759 \mathrm{~g} / \mathrm{kg}$ )

(Mean values and standard deviations for six samples/group)

\begin{tabular}{ccccc}
\hline & \multicolumn{2}{c}{$\begin{array}{c}\alpha \text {-tocopherol } \\
\text { (mg/kg } \\
\text { wet weight) }\end{array}$} & \\
$\begin{array}{c}\text { Dietary } \\
\text { group* }\end{array}$ & Mean & SD & & $\begin{array}{c}\text { Fat } \\
(\mathrm{g} / \mathrm{kg})\end{array}$ \\
\hline 1 & $3 \cdot 6$ & 0.9 & 30 \\
2 & 3.8 & 0.8 & 26 \\
3 & 3.9 & 0.9 & 31 \\
4 & 4.5 & 0.8 & 28 \\
\hline
\end{tabular}

* See Table 3 .

muscle more than that of muscle tissue. In group $2,0.2 \mathrm{mg}$ Se as selenite $/ \mathrm{kg}$ raised the Se level of liver $4 \cdot 3$-fold but that of meat about $3 \cdot 5$-fold.

Different levels of Se supplementation did not cause significant changes in the $\alpha$ tocopherol content of beef (top round, Table 4). The $\alpha$-tocopherol concentrations were higher than those in earlier measurements in beef produced in Finland (Piironen et al. 1985) presumably because all groups were given a constant amount of vitamin supplements throughout the experimental period.

\section{DISCUSSION}

Plant Se at both concentration levels (groups 3 and 4) was more effective than sodium selenite (group 2) in raising the Se content of muscle tissues. The finding was reported in earlier studies (Ku et al. 1972; Mahan \& Moxon, 1978; Goehring et al. 1984; Sankari, 1985). However, inorganic Se was as effective as plant Se in increasing the Se content of organs; only in the Se content of brains could a significant difference between groups 2 and 3 be observed.

The Se concentration of liver increased more than that of other organs in all dietary groups. The same observation had earlier been made in lambs (Lopez et al. 1968; Moksnes \& Norheim, 1983) and calves (Hidiroglou et al. 1985).

Different tissues responded to Se supplementation quite differently. Muscle tissue and liver were high responders to plant Se (increase 7.4-12.0 fold in group 4 ). The Se contents of heart, tendon, hair, pancreas and spleen were affected moderately (4.1-5.7 fold), while those of brains, kidneys and testicles increased only a little (1.4-1.9 fold).

The mean Se concentrations of different tissues in group 5 (bovine samples from the general production after start of Se supplementation via fertilizers in Finland) were generally near those of group 3 (plant Se at level $0.25 \mathrm{mg} / \mathrm{kg}$ feed). This is in accordance with the finding that Se fertilization has raised the Se content of feedstuffs to an average level close to $0.2 \mathrm{mg} / \mathrm{kg}$ dry matter (Ministry of Agriculture and Forestry, 1989). Liver and kidney, however, seem to have responded to fertilization more than they should have according to the present experiment. This may be a reflection of the present practice of supplementing the feed of calves with inorganic selenite in spite of the higher level of organic Se in feed.

The correlation between dietary and tissue Se is known to be linear at low concentrations, but at high dietary levels a plateau in tissue concentrations is reached (Groce et al. 1971, 1973; Mahan \& Moxon, 1978). In the present study, the Se content of muscle tissues did not reach a plateau, but increased linearly with the increasing Se content of the feed. The 
difference between groups 3 and 4 was significant $(P<0.05)$. In other tissues, the Se content seemed to reach a plateau in most cases, since the plant Se level of $0.40 \mathrm{mg} / \mathrm{kg}$ (group 4) did not raise the tissue Se level significantly compared with group $3(0.25 \mathrm{mg}$ plant $\mathrm{Se} / \mathrm{kg})$.

In Finland, the addition of Se to multi-nutrient fertilizers has increased the Se content of all agricultural products (Varo et al. 1988). The most important source of Se in the human diet is now meat and meat products with nearly $40 \%$ of the daily intake coming from this category of foods (Ekholm et al. 1990). In 1989, the average Se intake from meat, meat products and edible offals was about $0.045 \mathrm{mg} / \mathrm{day}$, and the total Se intake reached a level of $0.12 \mathrm{mg} /$ day at the energy level of $10 \mathrm{MJ}(2400 \mathrm{kcal})$ (Ministry of Agriculture and Forestry, 1989). Before the Se supplementation of fertilizers, in the mid 1970s, the contribution of meat and meat products to the daily Se intake was about $0.01 \mathrm{mg} / \mathrm{day}$, the total intake being about $0.03 \mathrm{mg} /$ day (Varo \& Koivistoinen, 1980).

The study was supported by the Farmers Meat Central, the Finnish Association of Academic Agronomists and the Ministry of Agriculture and Forestry. The fat analyses and the sampling of general beef production in the spring 1988 was kindly organized by the Research Institute of Meat Industry. The authors wish to thank Mrs Lena Jolkkonen, Miss Pirjo Nironen and Mrs Maija Ylinen for their technical assistance.

\section{REFERENCES}

Brown, M. B. \& Forsythe, A. B. (1974). The sample behavior of some statistics which test the equality of several means. Technometrics 16, 129-132.

Ekholm, P., Ylinen, M., Koivistoinen, P. \& Varo, P. (1990). Effects of general soil fertilization with sodium selenate in Finland on the selenium content of meat and fish. Journal of Agricultural and Food Chemistry 38, 695-698.

Finnish Association of Academic Agronomists. (1987). Selenium from milk and meat. Publication of Finnish Association of Academic Agronomists no. 102. Helsinki: Finnish Association of Academic Agronomists (in Finnish).

Gissel-Nielsen, G. \& Bisbjerg, B. (1970). The uptake of applied selenium by agricultural plants. 2. The utilization of various selenium compounds. Plant and Soil 32, 382-396.

Goehring, T. B., Palmer, I. S., Olson, O. E., Libal, G. W. \& Wahlstrom, R. C. (1984). Effects of seleninferous grains and inorganic selenium on tissue and blood composition and growth performance of rat and swine. Journal of Animal Science 59, 725-732.

Groce, A. W., Miller, E. R., Hitchcock, P. J., Ullrey, D. E. \& Magee, W. T. (1973). Selenium balance in the pig as affected by selenium source and vitamin E. Journal of Animal Science 37, 942-947.

Groce, A. W., Miller, E. R., Keahey, K. K., Ullrey, D. E. \& Ellis, D. J. (1971). Selenium supplementation of practical diets for growing-finishing swine. Joumal of Animal Science 32, 905-911.

Hidiroglou, M., Proulx, J. \& Jolette, J. (1985). Nutritional muscular dystrophy in calves. Effect of administering intraruminally selenium pellets to pregnant cattle. In Trace Elements in Man and Animals, Proceedings of the Fifth International Symposium on Trace Elements in Man and Animals, pp. 744-746 [C. F. Mills, I. Bremner and J. K. Chesters, editors]. Farnham Royal: Commonwealth Agricultural Bureaux.

Huttunen, J. K. \& Koivistoinen, P. (1985). Recent studies on selenium status and its relation to disease in Finland. In Trace Elements in Man and Animals, Proceedings of the Fifth International Symposium on Trace Elements in Man and Animals. pp. 796-800. [C. F. Mills, I. Bremner and J. K. Chesters, editors]. Farnham Royal: Commonwealth Agricultural Bureaux.

Ku, P. K., Ely, W. T., Groce, A. W. \& Ullrey, D. G. (1972). Natural dietary selenium, $\alpha$-tocopherol and effect on tissue selenium. Journal of Animal Science 34, 208-211.

Kumpulainen, J., Raittila, A.-M., Lehto, J. \& Koivistoinen, P. (1983). Electrothermal atomic absorption spectrometric determination of selenium in foods and diets. Journal of the Association of Official Analytical Chemists 66, 1129-1135.

Levene, H. (1960). Contributions to Probability and Statistics. Palo Alto: Stanford University Press.

Lopez, P. L., Preston, R. L. \& Pfander, W. H. (1968). Wholebody retention, tissue distribution and excretion of selenium 75 after oral and intravenous administration in lambs fed varying selenium intakes. Journal of Nutrition 97, 123-132.

Mahan, D. C. \& Moxon, A. L. (1978). Effects of adding inorganic and organic selenium sources to the diets of young swine. Journal of Animal Science 47, 456-466.

Ministry of Agriculture and Forestry. (1984). Proposal for the addition of selenium to fertilizers. Working Group Report No.7. Helsinki: Ministry of Agriculture and Forestry (in Finnish). 
Ministry of Agriculture and Forestry. (1989). Annual report. Working Group Report No. 34. Helsinki: Ministry of Agriculture and Forestry (in Finnish).

Moksnes, K. \& Norheim, G. (1983). Selenium and glutathione peroxidase levels in lambs receiving feed supplemented with sodium selenite or selenomethione. Acta Veterinaria Scandinavica 24, 45-58.

Mustonen, S. [editor] (1987). In Survo 84 Users Guide. Helsinki: University of Helsinki, Department of Statistics.

Oksanen, H. E. (1965). Studies on nutritional muscular degeneration (NMD) in ruminants. Acta Veterinaria Scandinavica 6, Suppl. 2, 1-110.

Oksanen, H. E. \& Sandholm, M. (1970). The selenium content of Finnish forage crops. Journal of the Scientific Agricultural Society of Finland 42, 251-254.

Piironen, V., Syväoja, E.-L., Varo, P., Salminen, K. \& Koivistoinen, P. (1985). Tocopherols and tocotrienols in Finnish foods: Meat and meat products. Journal of Agricultural and Food Chemistry 33, 1215-1218.

Sankari, S. (1985). Plasma glutathione peroxidase and tissue selenium response to selenium supplementation in swine. Acta Veterinaria Scandinavica 81, 1-127.

Sippola, J. (1979). Selenium content of soils and timothy (Phleum pratense L.) in Finland. Annales Agriculturae Fenniae 18, 182-187.

Varo, P., Alfthan, G., Ekholm, P., Aro, A. \& Koivistoinen, P. (1988). Selenium intake and serum selenium in Finland: effects of soil fertilization with selenium. American Journal of Clinical Nutrition 48, 324-329.

Varo, P. \& Koivistoinen, P. (1980). Mineral element composition of Finnish foods. XII. General discussion and nutritional evaluation. Acta Agriculturae Scandinavica 22, Suppl., 165-177.

Varo, P., Nuurtamo, M., Saari, E. \& Koivistoinen, P. (1980). Mineral element composition of Finnish Foods. III. Annual variations in the mineral element composition of cereal grains. Acta Agriculturae Scandinavica 22. Suppl., 27-35. 